\title{
Xenophobia and Collective Violence in South Africa: a note of skepticism about the scapegoat
}

Jonny Steinberg

Jonny Steinberg is Professor of African Studies at the University of Oxford and Visiting Professor at the Wits Institute for Social and Economic Research (Wiser). His most recent book is A Man of Good Hope. He is co-editor, along with Jan Beek, Mirco Gopfert, and Olly Owen of Police in Africa: The Street-Level View and of the Sage Handbook of Global Policing, co-edited with Ben Bradford, Beatrice Jauregui, and Ian Loader. jonny.steinberg@africa.ox.ac.uk.

\begin{abstract}
This article examines differing explanations for violence against foreign nationals in post-apartheid South Africa. It argues that the most compelling analyses in the scholarship draw from a family of arguments in the global literature that locates popular violence against outsiders within the context of declining sovereign power, explaining theatrical displays of force against enemies within as attempts at the retrieval of that power. To the extent that these arguments rely on the concept of a scapegoat, they are inadequate. More analytical attention needs to be paid to the scene of the encounters between the "us" and the "them" of collective violence.
\end{abstract}

Keywords: xenophobia; collective violence; South Africa; Somalis; migration On a recent trip to Hargeisa, the capital of Somaliland, I was asked, bluntly and a little rudely, why Somalis are so often killed in South Africa. This paper attempts to tackle 
that question. I review what I regard as the best and most insightful explanations of collective violence against foreign nationals in post-apartheid South Africa. My engagement with this literature is at once admiring and critical; I hope to show that it has been analytically fecund but also has limitations, and that these limitations speak to difficulties in accounting for collective violence more broadly.

The empirical material I draw upon in this article is quite specific. Between 2010 and 2014, I shadowed and documented the life history of a Somali man in South Africa by the name of Asad Abdullahi. His story is told at much greater length in $A$ Man of Good Hope (Steinberg 2015). While the material I draw upon is thus narrow inasmuch as it concerns one man's experiences, I believe that I have used it in a manner that speaks to more global questions.

But to begin with, what did my interlocutor in Hargeisa have in mind when he asked why Somalis are killed in South Africa?

Somalis head south in part because it is said that South Africa is the easiest place on the continent to establish a flourishing business. But on arrival, many Somalis find that difficult choices must be made. Somewhere in each major South African city is a neighborhood pretty much taken over by Somalis. These are safe spaces. There is density. The streets are filled with the sounds of the Somali language. The faces looking out of the windows in the buildings above are Somali faces. But there isn't much money to be made in these neighborhoods. The sorts of businesses that thrive there are of some scale and require the capital and the connections that only an elite class of Somalis in South Africa can access. There is work to be had in these spaces, as a shop assistant, for instance, or as a driver delivering goods, but the hours are punishing and the wages meagre. One has come all this way to make money, after all, not to be consigned to poverty in a strange land. 
It is generally possible to make money in South Africa only out among the poor, in the shack settlements at the edges of the cities, for instance, or in the small towns across the country whose populations have boomed over the last generation. One builds a shack or rents a small house, fills it with goods and begins to trade. It doesn't take much capital to do it. ${ }^{\mathrm{i}}$

But the price of becoming a petty capitalist is to lose your security. The people among whom you live make no bones that they do not like you. Your shop fills every day with cash. Were a group of armed men to walk through the door, shoot you in the head, and take your money, everyone knows that nobody would care, including the agents of the criminal justice system.ii The police would certainly go through the motions of starting an investigation. But the case would soon be sucked into a hole of sheer inertia and vanish.

There is another form of violence that my interlocutor in Hargeisa was thinking of. Periodically, the accretion of day-to-day insults and jibes swells into something more oceanic. Crowds form, and they drive Somalis from their businesses, forcing them to flee, leaving their stock and their personal possessions to be looted by the crowds, and their homes to be set alight. This happens on a small scale somewhere in South Africa all the time. For two weeks during May 2008, it happened in towns and cities in every province in South Africa. During that time, more than 100,000 people fled their homes; sixty-three people were murdered (Masigo et al. 2009). ${ }^{\text {iii }}$

The criminal justice system is as unenthusiastic about investigating and prosecuting these crimes as it is about the quotidian robberies described above. To date, a decade after the violence of May 2008, one person has been convicted for one of the sixty-three murderers committed at that time (Laganparsad 2015).

It is in the wake of stories like these that Somalis ask why their fellow 
nationals are treated so poorly in South Africa. There is, of course, a body of scholarly commentary on violence against foreign nationals in South Africa. I wish to start by focusing here on the work of one of those scholars, Loren Landau, for his work is especially thoughtful and powerful.

Landau $(2004,2010)$ conjures the scene of a theatrical production. The performers are South African police officers, the audience consisting of the South African poor. Landau points out that by 2007, the last calendar year before the violence of May 2008, South Africa deported more than 300,000 foreign nationals per annum. Picking people off the streets, deciding whether they had a right to be in South Africa, throwing them into a van if it was decided that they were not—by 2007, this had become an everyday part of policing performed as a matter of course in the poorest parts of South Africa's cities and towns (Altbeker 2005:166-79).

Police stop people in public spaces and quiz them about their ethnicity, their nationality, their origins. The tests determining pedigree are home-grown and haphazard. For instance, civilians are asked to translate the word "elbow” from English into Zulu. Whether one knows that the Zulu word is indololwane and, if one does, how one pronounces it, is said to be a sure test of whether one is South African (Lubkemann 2000:58-9). These procedures are, of course, extra-legal and are performed primarily to line the pockets of police officers. But they are made possible by government policy.

The South African poor recognize these street-side practices immediately. For it is precisely what apartheid police did to their own forebears a generation earlier. And that is Landau's point. At the heart of urban apartheid, after all, was the anxiety that urban space was by its nature always too full, that the primary task of the forces of order was to empty it, again and again; a this work of emptying was never done 
and ought thus to be repeated ad infinitum. It fell to those who governed urban space to name, to classify, to catalogue, every last soul who wandered through thethe city, for to allow anybody to be unclassified was to leave the authorities unable to read the city, unable to go about the perpetual task of ridding it of those who do not belong.

The work police officers perform before an audience of the urban poor is old work with deep resonance. It borrows a conception of the city fashioned by the fears of a racial minority. Except that the performance now does new work, for the boot is on the other foot. To be black and deemed South African is to belong to the dangerous city, by virtue of the fact that other black Africans do not.

And so here is the beginning of one answer to the question my interlocutor in Hargeisa posed. When crowds gather to attack foreign nationals, they are, according to the logic of this story, becoming police auxiliaries, after a fashion, or, at very least, attempting to finish the job the police started, until, that is, the city fills again with those who don't belong, and the work starts all over again. And it is as well that the work must continue, for in perpetually carrying on the task of emptying the city, one is reaffirming that one belongs.

And when armed robbers murder a shopkeeper and the police investigation stumbles and then falters, this too is productive work. For it shows that those who do not belong remain unrecognized, even when they are murdered. The state apparatus does not click its heels and spring into action on behalf of the corpses of those who should not be here.

It is a powerful argument, in part because of its many ironies. South Africa's national liberation project has given birth to a "demon”—“a society prepared to kill to rid itself of those retarding its post-apartheid renaissance.” And yet this new demon, ironically, rides on the back of an old demon, for in its targeting of an enemy within 
the new society it finds itself continuing "an extended history of South African statecraft that both induced the conflict and hamstrung attempts to address it" (Landau 2010:214). Not only did the old not die, the argument suggests; it lives on in the mentalities of the very people to whom it was cruelest. The fears of a white minority have shaped the ways in which the urban poor now express their claims to the city, the country, the future: the irony could not be more bitter.

It is, as I say, a powerful argument, but it nonetheless requires interrogation. I wish to start by exploring what I understand to be some of its main antecedents, for it takes its place, I contend, in a family of arguments that has acquired powerful currency in the global academy.

There are any number of places where one might begin an account of this family of scholarly arguments. For the sake of convenience, let us choose a widely read story, told by Eric Hobsbawm in his 1995 book The Age of Extremes. Something happened in the early 1970s, Hobsbawm says; precisely what, we cannot say, but the sovereignty of states began to diminish. Everyone who once believed that they had a measure of control—over the flow of people, goods, and money, over the meanings of symbols, over the narrative of what the world is and why — found that they had less control. Everyone who thought that they could ameliorate the business cycle, or control the rate of unemployment, or command the allegiances of citizens, or maintain the integrity of borders, found that they had less power over the world than an accretion of old expectations suggested.

That is the foundation of the story, an unsatisfactorily diminished quotient of sovereign power. The next building block is the idea that from the loss of this power follows an attempt to reconstruct a phantasmagorical version of it, that to exercise power today is, in part, at any rate, to act out a form of sovereignty that has 
diminished.

The variations of this argument are legion. Here I pick just a few. Among the most sophisticated I have come across is David Garland's account of the rise of punitive populism and mass incarceration in the United States and Britain in his 2001 book The Culture of Control. In the last quarter of the twentieth century, Garland argues, the notion that a strong state could control crime levels through the exercise of bureaucratic power and criminological expertise lost credibility in these societies. People had to come to terms, for the first time in generations, with the fact that the state could not control levels of crime. The cultural responses to this unpleasant new knowledge, Garland argues, were complicated and contradictory. On the one hand, acceptance: In everyday life, crime was increasingly seen as a normal hazard, and crime avoidance activity became routinized. Life became more and more organized around the anticipation of risk.

But, at the same time, late modern society engendered expressions of denial about the state's eroding control. One form that this took was the virulent re-assertion of state sovereignty through theatrical displays of coercion, the escalating use of incarceration and the evolution of warlike language to describe the work of the justice system. And so with this denial came the idea that there was an enemy within, that categories and classes of people who had always been among us, a part of us, were no longer so. Another pathological response, Garland argues, was the voicing of anger as a proxy for real control, the satisfaction of vengeance as a substitute for the satisfaction of being able to shape the world. Hence, the rise of increasingly severe forms of punishment.

These proxies for control are so very productive, Garland argues, for their affective power is immense. Collective rage comes to constitute a common ground on 
which to stand. There thus arises the paradoxical situation in which real power and real authority are generated by the very act of protesting against their loss.

Writing in the 1990s, Garland was accounting for a punitive turn in the formal justice systems of two advanced capitalist countries. But at much the same time, a host of scholars, most of them anthropologists, studying phenomena a world away from Garland's North Atlantic, were making remarkably similar arguments. I am talking here about a burgeoning ethnographic literature that emerged in the unstable aftermath of the Cold War on ethnic riots, xenophobic attacks, and the mobilization of civilians in civil war. Stanley Tambiah’s and Veena Das’s respective works on Southeast Asia, for instance (Tambiah 1996; Das 1990); Carolyn Nordstrom’s (1997) account of the mobilization of civilians to commit violence in the Mozambican civil war; Valentine Daniel’s (1996) writing on collective violence in Sri Lanka; Robert Hayden’s (1996) work on ethnic cleansing in Yugoslavia. In all of these works, collective violence takes place in the context of declining state power, the unthreading of old certainties, the eroding ability of sovereigns to control borders, to regulate movement. And all argue, in one form or another, that the ethnic categories that govern collective violence are products of state policies such as censuses, partitions, and discriminatory policing. As with Garland's punitive turn, ethnic violence is at once the expression of a bitter denial of lost foundations and a construction of proxies for them. Most important of all, the terrain is named, and the charge led, by weakening states.

And so a family of closely-related ideas was circulating the academy during the 1990s. To my knowledge, this intellectual approach to collective violence first settled upon xenophobia in post-apartheid South Africa in the form of Jean and John Comaroff's remarkable essay on mountain fires, published in 2001. Beginning with 
an account of how popular sentiment was mobilized against allegedly alien plant species in the wake of a raging fire on Cape Town's Table Mountain, it morphed into a meditation on popular anger against foreign nationals. It is in retrospect an enormously prescient piece. Several years before the mass violence of May 2008, it points to a weakening sovereign state's theatrical policing of foreign nationals before audiences of the poor. These are displays of "mass mediated ritual excess," the Comaroffs write, “directed to producing state power and national unity” (2001:254). And in the fact of a national project that cannot be realized, fears and uncertainties are mobilized to launch a perpetual assault upon an intruder.

And so we have turned full circle and are back with Loren Landau’s fine essay. I choose Landau's essay as the centerpiece because it is, in the South African context, the most fully realized and satisfying. It detects in the ways that postapartheid police and crowds cleanse the city the shadow of an old mentality, originally deposited in the world by the statecraft of a white minority. It suggests that the ways in which white people made demons of black people has crossed a racial boundary. When they express demonization, Landau implies, black South Africans are drawing on a white bequeathal. The connections he makes between present and past are thus perhaps best described as symphonic or resonant; there is a complexity in what he says which suggests that his is indeed an account of the real world.

I said earlier that I would like to sound a note of skepticism about this family of arguments. It seems to me that in many versions of the argument that sees collective violence as a symptom of, and a rebellion against, the inadequate power of traditional institutions to deliver their projects, there is something amiss at the heart of the most fleshy, empirical moment in the whole scene: the relationship between people, or more 
specifically, between the "us" that commits collective violence and the "other" upon whom violence is inflicted.

The scene as conjured threatens to become a solipsistic one. The "us" fabricates an "other" in order to become an "us.” There is, phenomenologically speaking, no relationship between people; there is only a collective fantasy. To put it another way, those who are the object of collective violence are scapegoats. They are taking the blame for something that has nothing to do with them. They are thus substitutable.

In her writing on anti-Semitism in the immediate wake of the Holocaust, Hannah Arendt recounts a joke that circulated in liberal German circles after the First World War.

"An anti-Semite," the joke begins, "claimed that the Jews caused the war; the reply was: Yes, the Jews and the bicyclists. Why the bicyclists? asks the one. Why the Jews? asks the other" (Arendt 1979:5).

Arendt is irritated by this joke. "The theory that the Jews are always the scapegoat implies that the scapegoat might be anyone else as well," she writes. "It upholds the perfect innocence of the victim, an innocence which insinuates, not only that no evil was done but that nothing at all was done which might possibly have a connection with the issue at stake” (ibid.:5).

This argument is, for Arendt, unsatisfactory. "[A]n ideology which has to persuade and mobilise people cannot choose its victim arbitrarily,” she writes. "[I]f a patent forgery like 'The Protocols of the Elders of Zion' is to be believed by so many people that it can become the text of a whole political movement, the task of the historian is no longer to discover a forgery. Certainly, it is not to invent explanations which dismiss the chief political and historical fact of the matter: that the forgery is 
being believed,” (ibid.:7). In her customarily bracing manner, Arendt is suggesting that there is a connection between why Jews are hated and what Jews do.

This seems to me a crucial point to take on board when examining violence against foreign nationals in South Africa. It is an approach that pays due attention to what those at the scenes of violence say, think, and feel. Or, to put it differently, it brings real exchanges between human beings back into the analysis.

What is it that Somalis in South Africa do? Landau talks of a theater that the police perform before an audience of the poor. What sort of theater do Somalis perform in the shack settlements of the peripheries of cities and in rural towns? What is it that the South African poor see them do?

One way to describe them is as extreme versions of Max Weber's Protestants. Weber's Protestants are one-track-minded people. Everything they come across in this world they turn into instruments, into means. And their end is just one: it is accumulation. They have this mentality because their horizons extend far beyond the temporal world. They do not know whether they have been elected for a place in heaven, and this uncertainty makes them anxious. Their incessant accumulation is a symptom of their anxiety; they wish to convince themselves that they are indeed the sort of people who have been elected by living lives that an elected person would live: industrious, accumulative.

Many Somali entrepreneurs in South Africa, I would venture, are much more singlemindedly instrumental in their quest to accumulate than the entrepreneurs Weber was imagining when he wrote The Protestant Ethic and the Spirit of Capitalism. Take, for instance, Asad Abdullahi, whose life I documented in my book, A Man of Good Hope. Weeks after his arrival in South Africa, Asad found work as a 
storekeeper in a Somali-owned spaza shop in a small town in the Eastern Cape. His wage was ZAR1,400 a month, about a quarter of what workers in the platinum mines were earning at the time and over which they were soon to rebel. In exchange for this very modest wage, Asad gave his life, all of it. He opened the shop at dawn and kept it open until late at night, taking his meals, and indeed, making his bed, on the premises. For six days of each week, he left only to use the communal toilets on his block and to drive to the nearest town to replenish supplies. He had Sundays off. For the duration of this employment he saved pretty much everything he earned. His employer provided the food for his meals and the petrol for his car. His only purchases were a modest pile of casual clothes and the occasional stash of khat which he chewed with friends on Sundays. The rest was capital; within six months of arriving in South Africa, he had saved enough money to start his own business.

Like Weber's Protestants, Asad was consumed with anxiety about what would become of him after his death, or, at very least, with the legacy he would leave. As a Somali, he learned as a boy the names of the last two dozen men in his paternal lineage. This sense of a deep past was coupled in his internal world with a sense of a deep future. His quest, seldom articulated on the surface of his consciousness, but often detectable in the decisions he made in difficult situations, was to effect a revolution in his lineage (Jackson 2008). What he did during his time on this earth, he believed, should bequeath to his descendants lives his forebears could not have imagined. And this required, in the first instance, accumulating enough money to move again, preferably to the United States or northern Europe. South Africa, for Asad, was not the terrain on which he lived his life. It was a way station, good only for the resources it might yield. His quest was to harvest these resources and no more. 
What do the South African poor see when they observe a man like Asad in their midst? This is a good moment to introduce the work of Tamlyn Monson, for she has recently provided an enormously thoughtful answer to a similar question (Monson 2015). Like Landau's, her project is ambitious: it is to account for violence against foreign nationals in South Africa. And, to her credit, she is preoccupied with what it is that South Africans see foreign nationals do and why this might provoke anger. She thus avoids the analytical problem of the scapegoat identified by Arendt. What follows is a brief exposition of her argument.

Monson points out that the overwhelming majority of incidents of collective violence against foreign nationals are concentrated in shack settlements established on the urban periphery within living memory. This combination of time and geography is crucial, she argues, for most residents of these settlements either have memories of their inception or are steeped in folkways about what their inception might mean. They were created by land invasions, and thus by defiance, and are understood by their residents as achievements to be defended. Moreover, most were established either in the late apartheid period or during the transition to democracy and are thus inserted by their residents into a national narrative, one that ends in fully-fledged urban citizenship. ${ }^{\text {iv }}$ We initiated a quest for urban citizenship by defying the law and invading land, according to the narrative Monson recounts. And now the democratic state we voted into power will carry us over the threshold into citizenship-proper by providing us with brick-and-mortar houses, with proper amenities and infrastructure, and with schools that will elevate our descendants into the realm of urban insiders.

By the mid-2000s, this narrative had begun seriously to fray. It was now that collective action in protest against poor service delivery and corruption began in earnest. It was now that talk arose among residents that the democratic state was 
beginning to renege on its role in the narrative and leave residents permanently on the threshold of citizenship. And it was now that collective violence against foreign nationals began in earnest. These connections, Monson argues, are vitally important. By virtue of the lives they lived, disconnected from their neighbors, steeped in the hard labor of accumulation, flagrantly uninterested in the increasingly urgent waves of collective action against government, those whose presence in the settlements was expressly itinerant were announcing themselves as free riders. They had done nothing to found the settlements in which they lived and had no interest in their destinies. They had failed a harsh test of citizenship.

Monson conducted her fieldwork in two adjacent settlements in Atteridgeville outside Pretoria. The localism of her work makes it is difficult to evaluate how well her argument might travel to other places in South Africa where collective violence against foreign nationals has been prevalent. But her localism also brings with it an immersion in at least some of the language of many of the people she has interviewed. What she heard in their voices was an anger that was political and ethical. Her subjects, she insists, were not autochthons, steeped in prejudice against those bred in other soils, but self-styled citizens who believed that those who cannot live up to the republican virtues that founded their informal settlements have no right to live there.

Monson's dissertation can be justly described as an apologetics. Her aim is to refigure the meaning of South African "xenophobia,” such that we come to understand its rationality. She wants us to know that what we call "xenophobia" is grounded not just in the history of the struggle for freedom in South Africa, but on a foundation of political values. Indeed, she would suggest that the very word "xenophobia” is born from incomprehension, from a failure to pay due respect to the politics of the poor. 
And yet the apologetic character of Monson's argument also signals its limitations, for while it might account for anger and ethical disapproval, it does not account especially well for violence. Indeed, on the few occasions in her dissertation when Monson does deal with violence, she talks of it as "excess.” She stresses that her interviewees condemn it. It is thus something performed by others and carries no explanation of itself. Or, to put it another way, Monson interviews those aspects of human beings who condemn violence; the impulses to commit violence are buried the moment Monson’s interviews begin.

So, let us return again to the question: What is it that people see when they see a person like Asad?

I wish to look first at the phenomenon of armed robbers murdering or injuring storekeepers and walking away with their takings, and then at the mobs that burn shops and homes and sometimes kill.

My interlocutor in Hargeisa told me that when Somalis are slaughtered in my country, the South African criminal justice system stands by. He is not wrong, but the manner in which he frames his observation may be misleading. It is probably more accurate to say that the justice system stands by when Somalis are murdered in informal settlements because it stands by when just about anybody, but for a select few, is murdered in informal settlements. ${ }^{\mathrm{v}}$

There is, frustratingly, no data in South Africa that records the disparities in the effectiveness of the criminal justice system across urban space. But we do have some idea. The 2014 report of the Commission of Enquiry into Policing in Khayelitsha, for instance, a township of about a million people on the southeastern periphery of Cape Town, found that station-level investigative work had pretty much ground to a halt (O’Regan \& Pikoli 2014:362-74). 
This observation is not, I should hasten to say, the end of the story of Somali shopkeepers murdered for their day’s takings. It is the beginning. The question of what people do to secure themselves where nobody has a monopoly on violence is among the oldest and deepest in modern social theory. And in regard to urban space in contemporary South Africa, some of the best and most illuminating work has studied the institutions, relationships, and politics that evolve in collective quests to avoid and commit harm (Buur 2006, Cooper-Knock 2014, Von Holdt 2013). Somali shopkeepers have an unusual place in this story. I tread cautiously here because the moral and political implications of what I say are delicate. To put it simply, the single-minded accumulators I described earlier, who fashion everything in their worlds into means, take extreme risks, not just with their capital, but with their lives. This was the most striking feature of the life trajectory of Asad Abdullahi, the Somali entrepreneur I studied. He would set up shop among the poor, something terrible would befall him or his business partner, he would retreat into safe space, pause, and then return to do business among the poor, always somewhere new and strange, where he was alone, without networks, and without protection. Such was the pattern of his existence for the nine years of his South African life.

Asad did not return to the life of danger with alacrity. He did so with great reluctance and enormous fear and only after safer ways of making money did not work out. But he did keep returning, always in as vulnerable a position as he had been in when he was last in business. In his rationalizations for doing so, powerful forces of denial were at work. One afternoon during his time in Khayelitsha, for instance, a group of young men walked past his store. On a whim, one of them pulled out a gun, shot at Asad and his business partner, pocketed the gun, and strolled on down the street. 
“That night,” Asad told me, "I realized that if I properly faced the truth I would have to leave Khayelitsha straight away and never come back. I woke up the next morning and returned to work.”

Although the form his reasoning took was liquid and opaque, Asad was reasoning nonetheless. In his time on this earth he wanted to effect a revolution in the history of his lineage. His sojourn in South Africa could not unravel this project. And so he kept returning to areas of danger because to cease to accumulate would be to cease living a meaningful life.

What does a life like Asad's look like to those who watch it? What sorts of meanings does it emit to an audience of the South African poor? More particularly, what does it mean when a distinct, identifiable group of people keep returning to places of danger without any meaningful protection in order to accumulate money?

I went to visit Asad one afternoon in 2010 at his home in Blikkiesdorp, a shack settlement on the outskirts of Cape Town, and found him several blocks from his shack helping a new Somali family move in. The new people had bought their site from a Somali family who were leaving because their shop had been looted and burned to the ground. A group of young South African men was playing dice some one hundred yards or so away, and I went to join them.

At one point, one of them remarked: “I wonder how long these new ones will last. Will the dice tell us that?”

It struck me then what it was that these young men saw. When Asad's cousin and business partner, Kafi, was killed in their store in the hamlet of Sterkstroom, Asad sold the business to a Somali family who now opened shop in the very space where Kafi had died. And when Asad and his business partner were robbed and brutally assaulted in their shop in Mabopane outside Pretoria, Asad sold his share of the 
business to a Somali man. Once again, the man went to work at the very scene where Asad's customers had watched armed robbers kick his head like a football. In each case, South Africans would observe a pattern. A Somali dies or is injured. The survivors of the murdered one sell. The new Somali entrepreneur settles in, as unprotected as the last. And if he is killed, his survivors will sell in turn. And so on. This is a little speculative, I admit, but I wonder whether, among the audiences that watch Somalis live their lives, a connection is made between their strange and distinctive form of money-making and a propensity to die. I wonder, too, whether this connection between accumulation and death is understood as a perversion, a moral deficit, as if a human being who refuses to take sufficient measures to protect himself, whose intent is simply to make money — even at the cost of his life, and more especially, at the cost of the lives of the women and children in his care-is in a state of dishonor, and, in a dark sense, deserves the violence meted out on him. ${ }^{\mathrm{vi}}$

And what of collective violence? What of crowds that loot and burn and sometimes kill? There are forms of human activity that I think are best approached with analytical modesty.

Toward the end of her recent essay on suicide in Eastern and Southern Africa, for instance, Megan Vaughan adopts a tone of analytical resignation, or, perhaps more accurately, a sense of wonder.

“Faced with real individual cases, rather than anonymous statistics," she writes, "most of us falter in our understanding of suicide... Beyond the very human desire to understand what motivates an individual to end his or her own life there often lingers an awed sense of the enormity of the act, and a feeling that the person was ‘moved’ by something beyond his or her control.” (Vaughan 2012:246). 
In a similar spirit, Michael Jackson writes of "situations [that are] too complex and involve too many points of view to allow much analytical certainty.” Often, in such cases, he writes, "what passes for theory is ... a defense against the anxiety of the inexplicable, the ineffable, the contradictory, the ambiguous.” Where scholarship “can only go partway in explaining all that is the case," he asks, "does our task then become one of judging when to tell and when to show?” (Jackson 2012:172).

Violent crowds, I would suggest, ought to instill a sense of analytical modesty. It is striking how the most famous and durable theories of crowds in social theory are so speculative, and rely so heavily upon imaginative exercises. ${ }^{\text {vii }}$

In the spirit commended by Jackson, I wish to end by telling a story. I am fortunate, if that is the right word, inasmuch as a South African I got to know very well shared with me, in an unusually intimate manner, his experience of being in a violent crowd attacking a foreign national. It was a mental rather than an empirical experience, since the crowd he imagined himself joining did not, in fact, materialize. But his experience is invaluable nonetheless.

The setting was a rural village on the periphery of the Eastern Cape town of Lusikisiki. And the man, whom I named Sizwe Magadhla when I initially wrote about him, was not yet thirty and had just started a spaza shop in the village in which he had spent his life (Steinberg 2009). He was, at the time, consumed by the problems that attend to becoming an entrepreneur in a world where ties and obligations bear down heavily. He wondered a great deal, for instance, about how he might negotiate the envy of his peers. He knew that he was becoming wealthy by village standards, but the signs of his wealth were not yet visible. He feared what people would say and do once he had renovated his house and bought a new car. How best to protect his wealth? By sharing it? If so, with whom? By concealing it? How could this be done if 
he was to enjoy it? By purchasing magical defenses against envy? Effective medicine, he believed, was prohibitively expensive.

It was while he was preoccupied with these troubles that Sizwe met John, a Malawian businessman who operated a shop from the Lusikisiki town center. John offered Sizwe a magical escape from his difficulties.

"What he wanted me to buy from him,” Sizwe told me, "was a very powerful magic. I go to the warehouse store in town to stock up, and I spend, say, R775. I load my bakkie, I drive back to my village, I get the boys around my house to unload and pack the shelves. Then I go to my bedroom and lift the pillow. Lying there on my bed is the R775 I spent at the warehouse store. I have stocked up for free.”

Sizwe was uneasy about the ethical implications of John’s offer. "I am aware that what I would be doing is stealing," he said. "But I would not use this magic on a small, struggling shop owner like me. I would use it on the big warehouse stores.”

John's offer turned out to be an especially intricate version of a 419 scam. For the magic to work, Sizwe would have to make a large down payment, then perform a ritual on the grave of his great grandfather, then make another down payment, and so on. By the time Sizwe realised that he had been duped, he had given John R14,000, more than half of his savings. To his enduring shame, he would see John's shop every time he made the trip to town. He could not go to the police, as he believed that he lost his money while conspiring to commit a crime.

Six weeks or so after he and John cut ties, Sizwe was in town eating lunch at a restaurant. "I heard gunshots," he told me, “I looked out the window and I saw people running, all in the same direction. I heard shouts. I thought to myself: they are finally attacking the amakwerekwere (foreign nationals). They are rounding up the amakwerekwere and they are killing them in the streets. I did not even finish my 
lunch. I went to join the people. It was only when I got to the front of the crowd that I understood what had happened. The Standard Bank had just been robbed. One of the robbers had been shot and killed outside the bank. The crowd had come together to see his corpse.”

I am tempted to leave the story as it stands for fear that anything I say about it will detract from it. But perhaps a few observations are in order. One is that the figure the hyper-accumulator, the person on South African soil only to accumulate, is a source of such strong and conflicted feelings. He is in a sense less (or more?) than human, for he seems not to be constrained by ties and obligations. If there are networks in his life, they exist in some invisible hinterland beyond South African borders and only assist in the task of accumulating. He is thus a source of dangerous temptation, for his ethereality suggests that he is freed from ties of reciprocity. He provokes fantasies animated by greed and envy and thus exposes an inner darkness. It was for this that Sizwe wished to punish John and all of his kind.

These very difficult feelings about foreign entrepreneurs are by no means idiosyncratically just Sizwe's. In January 2015, in the wake of yet another episode of collective violence against foreign nationals, South Africa’s Minister of Small Business Development, Lindiwe Zulu, made an extraordinary statement. "Foreign business owners in South Africa’s townships,” she said, “cannot expect to co-exist peacefully with local business owners unless they share their trade secrets” (Magubane 2015).

Zulu did not elaborate upon the secrets of which she spoke. She may have been referring to magical means, or perhaps to the existence of international networks through which foreign businesspeople access capital and markets. Either way, she was saying that it was not acceptable to live these hyper-accumulative lives in front of 
South African audiences. One must either share one's secrets or be subjected to murderous anger. She has provided a most unfortunate answer to the question I was asked in Hargeisa.

\section{Conclusion}

Among recent scholarship on violence against foreign nationals in South Africa, there is work that is rich in insight and analytical sophistication. The argument that such violence is connected to an incomplete and, indeed, impossible-to-complete, project of national emancipation; that the demon this incomplete project targets is constructed in part by a legacy of white minority statecraft; the idea that an analysis of collective violence should be grounded in a history of urban settlement and the politics that this demographic movement spawned — these are all extremely fertile ideas.

I would add, though, that the ideology that creates a demon cannot create a demon out of anybody. Far more attention needs to be paid to the quotidian practices of those who give offense and to the scene of the encounter between them and those who rise against them. I would also suggest that the closer we get to this scene, the more social theory reveals its limitations; we would do well to understand that the tools that serve us best in this moment are tools of observant description.

\section{References}

Abdi, Cawo. 2015. Elusive Jannah. Minneapolis: University of Minnesota Press. Altbeker, Antony. 2005. The Dirty Work of Democracy: A Year on the Streets with the SAPS. Johannesburg: Jonathan Ball. 
Arendt, Hannah. 1979. The Origins of Totalitarianism. New York: Harvest.

Buur, L. 2006. “Reordering Society: Vigilantism and Expressions of Sovereignty in Port Elisabeth's Townships.” Development and Change 37(4): 735-57.

Canetti, E. 1984. Crowds and Power. Trans. Carol Stewart. New York: Farrar, Straus and Giroux.

Carroll, Stuart. 2017. “Thinking with Violence.” History and Theory 55: 23-43.

Comaroff, Jean and John L. Comaroff. 2001. "Naturing the Nation: Aliens, Apocalypse and the Postcolonial State.” Social Identities 7(2): 233-65.

Cooper-Knock, Sarah-Jane. 2014. "Policing in Intimate Crowds: Moving Beyond 'the Mob’ in South Africa.” African Affairs 113 (453): 563-82.

Daniel, E.Valentine. 1996 Charred Lullabies: Chapters in an Anthropology of Violence. Princeton, N.J.: Princeton University Press.

Das, Veena. 1990 Mirrors of Violence: Communities, Riots and Survivors in South Asia. Delhi: Oxford University Press.

Freud, Sigmund. 1959. Group Psychology and the Analysis of the Ego. Trans. James Strachey. New York: Norton.

Garland, David. 2001. The Culture of Control: Crime and Social Order in Contemporary Society. Oxford. Oxford University Press.

Hayden, Robert. 1996. “Imagined Communities and Real Victims: SelfDetermination and Ethnic Cleansing in Yugoslavia.” American Ethnologist 23(4): 783-801.

Hobsbawm, Eric. 1995 Age of Extremes: The Short Twentieth Century 1914-1991. London: Abacus.

Holston, James. 2008. Insurgent Citizenship: Disjunctions of Democracy and Modernity in Brazil. Princeton: Princeton University Press. 
Horowitz, Donald. 2001. The Deadly Ethnic Riot. Berkeley: University of California Press.

Jackson, Michael. 2012. Between One and One Another. Berkeley: University of California Press.

—. 2008. "The Shock of the New: On Migrant Imaginaries and Critical Transitions.” Ethnos: Journal of Anthropology 73 (1): 57-72.

Laganparsad, M. (2015) “More than 350 Foreigners Killed—But Only One Murder Conviction.” Sunday Times (South Africa). April, 19, 2015.

Landau, Loren. 2010. "Loving the Alien? Citizenship, Law and the Future of South Africa’s Demonic Society.” African Affairs 109: 213-30.

—. 2004. "The Laws of (In)hospitability: Black Africans in South Africa.” Forced Migration Working Paper Series 7. Forced Migration Studies Programme, University of the Witwatersrand, Johannesburg. Lubkemann, Stephen. 2000. “The Transformation of Transnationality Among Mozambican Migrants in South Africa.” Canadian Journal of African Studies 34(1): 41-63.

Le Bon, Gustov. 1902. The Crowd: A Study of the Popular Mind. New York: Dover. Magubane, Kulukane. 2015 “Reveal trade secrets, Minister tells foreigners.” Business Day. 28 January 16.

Masigo, J. with L. Landau and T. Monson. 2009. “Towards Law, Tolerance and Dignity: Addressing Violence against Foreign Nationals in South Africa.” report. Pretoria: International Organization for Migration.

Monson, Tamlyn. 2015 “Citizenship, 'Xenophobia’ and Collective Mobilisation in a South African Settlement: The politics of exclusion at the threshold of the state.” Doctoral Dissertation, London School of Economics. 
Nordstrom, Carolyn. 1997. A Different Kind of War Story. Philadelphia: University of Pennsylvania Press.

O’Regan, K. and V. Pikoli. 2014. “Towards a Safer Khayelitisha: Report of the Commission of Inquiry into Allegations of Police Inefficiency and a Breakdown in Relations between SAPS and the Community of Khayelitsha.” Cape Town.

Steinberg, Jonny. 2016 “How Well Does Theory Travel? David Garland in the Global South.” Howard Journal of Crime and Justice. 55(4) 514-31.

- 2015. A Man of Good Hope. London: Jonathan Cape.

_. 2009. Three Letter Plague: A Young Man’s Journey Through a Great Epidemic. London: Vintage.

Tambiah, Stanley J. 1996. Leveling Crowds: Ethnonationalist Conflicts and Collective Violence in South Asia. Berkeley: University of California Press.

Thompson, Daniel. 2016. "Risky Business and the Geographies of Refugee Capitalism in the Somali Migrant Economy of Gauteng, South Africa.” Journal of Ethnic and Migration Studies 42 (1): 120-35.

Vaughan, Megan. 2012. "The discovery of suicide in Eastern and Southern Africa.” African Studies 71(2): 234-50.

Von Holdt, Karl. 2013. “South Africa: The Transition to Violent Democracy.” Review of African Political Economy 40 (138): 589-604.

Weber, Max. 1930 (2005). The Protestant Ethic and the Spirit of Capitalism. Translated by Talcott Parsons. London: Routledge. 
${ }^{1}$ For recent ethnographic work on Somalis in South Africa, see Abdi 2015, Steinberg 2015, Thompson 2016.

2 In 2012, Daniel Thompson conducted interviews with proprietors of forty-three Somali-owned shops in various townships in Gauteng. Three had reported attempted robberies within the twenty-four hours prior to the interview. An additional four reported attempted or successful armed robberies within the previous ten days. The average for all forty-three shops was an attack every three months. (See Thompson 2016:128.)

${ }^{3}$ I should stress that those targeted in May 2008 were not just Somalis but an array of foreign nationals along with some South Africans. For a good account of the very complex ethnic geography of the violence, see Masigo et al. 2009.

${ }^{4}$ It should be clear from this account that Monson is strongly influenced by James Holston's work on land, space, law, and citizenship in Brazil. (See Holston 2008.)

${ }^{5}$ Among the few whose murders are likely to be thoroughly investigated are those residents of informal settlements with personal connections to the local police hierarchy. Some cultivate relationships with the police precisely to make themselves less killable. (See Steinberg 2016.)

${ }^{6}$ If this is so, it is a cause for dishonor among Somalis too. In her ethnography of Somalis in the South Africa, Abdi notes that it is frowned upon to bring women and children to a township because it is considered too dangerous. See Abdi 2015:154-71.

${ }^{7}$ I am thinking especially of Freud (1959), Le Bon (1902) and Canetti (1984). The view that crowd violence should be approached with analytical modesty is not uncontentious. Others have argued that crowd violence is as available to explanation as any other social phenomenon. From the discipline of history, see Carroll (2017) and from political science, see Horowitz (2001). 